\title{
Use Energy Efficiency, Eco-Design, and Eco-Friendly Materials to Support Eco-Tourism
}

\author{
Essam Metwally \\ Department of Interior Design, Faculty of Architecture and Design, American University of Madaba, Amman, Jordan \\ Email: esammet@yahoo.com,e.mohamed@aum.edu.jo
}

How to cite this paper: Metwally, E. (2019) Use Energy Efficiency, Eco-Design, and Eco-Friendly Materials to Support Eco-Tourism. Journal of Power and Energy Engineering, 7, 15-41. https://doi.org/10.4236/jpee.2019.712002

Received: November 8, 2019

Accepted: December 7, 2019

Published: December 10, 2019

Copyright $\odot 2019$ by author(s) and Scientific Research Publishing Inc. This work is licensed under the Creative Commons Attribution International License (CC BY 4.0).

http://creativecommons.org/licenses/by/4.0/

(c) (i) Open Access

\begin{abstract}
The term "Eco-lodge" is used to identify a type of nature-based tourism facility that will respond to the principles of ecotourism. The research aims to study, develop and design such types of facilities in an environmentally sensitive manner, using local materials or recycled materials, with a design that serves the environment and is consistent with the nature and cultural background of the place, through Energy Efficiency and Renewable Energies. This leads us to the ideas and foundations of seeking to preserve natural energy, respect the environment and reduce the impact of construction thereon. The research applies environmental and sustainable design standards to a proposed model designed by the Author for desert lodges, and the most important advantages of supporting ecotourism, by observing the principles of good design consistent with the local environment and culture, preventing the use of internal pollution sources, adapting to the climate, using alternative environmentally friendly materials, the efficiency of production and use of energy to promote the use of clean renewable energy. As important elements in the development of tourism and to help to preserve natural heritage and biodiversity. Such architectural solutions aim to achieve the objectives of eco-design, in terms of reducing the cost of energy in buildings, using natural energy instead of mechanical power systems, in addition to creating a healthy and comfortable environment.
\end{abstract}

\section{Keywords}

Adaptation to Climate, Natural Ventilation, Sick Buildings, Sustainability, Thermal Insulation

\section{Introduction}

The term green or sustainable architecture is a strongly used term in recent years. Most ancient civilizations have applied many of the existing foundations 
of green architecture. This leads us to the ideas and foundations of seeking to preserve natural energy, respect the environment and reduce the impact of construction thereon.

Now, the architecture has addressed all environmental problems and has used available environmental resources to meet local needs and adapt them to serve buildings, which is the result of thousands of years of experience. In which physical and psychological comfort is taken into consideration, by paying attention to the exclusion of materials and finishes that have proven to have a detrimental effect on health or on the environment and try to find alternatives thereto.

Therefore, the research recommends the importance of using natural materials while excluding modern chemicals that emit volatile organic compounds that are harmful to health, and the balance in the use of the thing between making good use and ensuring continuity of the foundations of green architecture, which must be used in a balanced manner. Eco-design shall take into account and complement the surrounding environment, not being far from it.

Objective: The term "Eco-lodge" is a name for a tourism industry product. It is used to identify a type of nature-based tourism facility that will respond to the principles of ecotourism. The research aims to study, develop and design such types of facilities in an environmentally sensitive manner, using local materials or recycled materials, with a design that serves the environment and is consistent with the nature and cultural background of the place, based on clean energy. Such a design method is called "Eco-design" which takes into consideration ecosystem criteria for the design and its integration with nature.

Search problem: Most people spend $90 \%$ of their time in a closed environment, poor design, in addition to using toxic compounds in some building materials, which may be the cause of the spread of many common diseases. Eco-design means constructing Eco-friendly buildings do not impact on or change the surrounding environment significantly, which has always been the goal of Architecture, but the construction materials that have been used, the use of modern technology, energy consumption, and the resulting pollution, in our current era, have contradicted such goal in more than one way.

Research Importance: As the environment problems began to increase in the world, attention began to turn to exploit and invest in the tourism sector by contributing to the reduction of environmental pollution.

The World Ecotourism Summit was held in Quebec City, Canada, in 2002, which was organized by the World Tourism Organization (WTO) in collaboration with the United Nations Environment Program (UNEP) to stimulate and motivate researchers, specialists and stakeholders in countries and governments to conduct further research and studies in the field of ecotourism, with the aim of managing, planning and using modern means and techniques to spread long-term environmental awareness, exchange experiences and acquire skills in order to find a mechanism to control the sources of degradation and environmental pollution and protect nature, cultural wealth and provide a better life for 
human.

Methodology: The research adopts an analytical framework based on the use of the "descriptive inductive approach", used to collect significant data from the literature and studies related to the research subject. The default location selected in a hot area of a similar climate and a desert nature. The second approach is the Applied \& Analytical approach; it is used in the analysis of the design of eco-tourism resorts. The research applies environmental and sustainable design standards to a proposed model designed by the Author for desert lodges. Through the design, the ideas, methods, and systems, mentioned in the research, were developed, like the efficiency of production and use of energy to promote the use of clean renewable energy, the use of thermal insulation products and the rational use and reuse of water resources in order to improve available resources and environmental processes, as an important element in the development of tourism and to help to preserve natural heritage and biodiversity.

\section{Environment and Ecosystem}

Scientists call the term "Environment" on all the external conditions and factors in which living organisms live and affect their biological processes. The ecosystem refers to any area of nature and its living organisms and living materials in their interactions with each other, with environmental conditions, and the exchange they create between living and non-living parts. It is clear from such a definition that it takes into account all the living organisms that make up the environmental community.

\subsection{Ecotourism}

Ecotourism has become one of the most developed and widespread concepts of sustainable development in the world. Many developing countries have become dependent on ecotourism as their main source of income and development, in addition to preserving the environment and practicing sustainable development.

We can develop the concept of traditional tourism development, in order to achieve its sustainability; by considering that tourism development is the process of satisfying the psychological needs of tourists and fulfilling their desires, without prejudice to the rights of future generations to enjoy the environment.

The fundamental difference between ecotourism and other types of tourism, as it tries to preserve the original environment, and does not use any techniques that disturb the ecological balance and biodiversity of this site, ensuring the preservation of the environment and the sustainability of its resources.

With the adoption of tourism as an entry point for development and the emergence of negative impacts on social and environmental aspects, the need to find new approaches to deal with tourism development has emerged, coinciding with in-creased interest in the environment and the emergence of the concept of sustainable development, which has been adopted to sustain development.

(Eco-design entails "designing with nature", for the benefit of the wider envi- 
ronment. Contemporary applications of eco-design include the development of new technologies as a transition to ecological sustainability-what Slessor (2001) characterizes as a movement from "high tech" to "eco-tech". Water sensitive urban design, nature's services approach, ecological restoration, permaculture, green buildings, biotechnology, wind farms, hybrid cars are all examples of eco-design. Eco-design combines environmentally benign philosophies, technologies, materials and legal standards (e.g. ISO 14,000) to meet current needs in ways that create lower levels of environmental impact while preserving biodiversity) [1].

\subsection{The Principles of Eco-Design of the Desert Lodges}

During its first decade, LEED (Leadership in Energy and Environmental Design) grew from one standard for new construction to a comprehensive system of six standards covering all aspects of the development and construction process. Green Building Council members, representing every sector of the building industry, developed and continue to refine LEED. The rating systems addresses eight major areas:

- Location and Planning;

- Sustainable Sites;

- Water Efficiency;

- Energy and Atmosphere;

- Materials and Resources;

- Indoor Environmental Quality;

- Innovation and Design Process.

To receive LEED certification, building projects satisfy prerequisites and earn points toward achieving different levels of certification. Prerequisites and credits differ for each rating system [2].

(BREEAM (Building Research Establishment's Environmental Assessment Method) was developed in the United Kingdom in 1990 and is the building environmental assessment method with the longest track record. BREEAM covers a range of building types including offices, homes, industrial units, retail units, and schools. Other building types can be assessed using Bespoke BREEAM ("bespoke" is another word for custom-made). When a building is assessed, points are awarded for each criterion and the points are added for a total score. The overall building performance is awarded a "Pass", "Good", "Very Good" or "Excellent" rating based on the score).

BREEAM major categories of criteria for Design and Procurement include the following:

- Management (commissioning, monitoring, waste recycling, pollution minimization, materials minimization);

- Health \& Wellbeing (adequate ventilation, humidification, lighting, thermal comfort);

- Energy (sub-metering, efficiency and $\mathrm{CO}_{2}$ impact of systems); 
- Transport (emissions, alternate transport facilities);

- Water (consumption reduction, metering, leak detection);

- Materials (asbestos mitigation, recycling facilities, reuse of structures, facade or materials, use of crushed aggregate and sustainable timber);

- Land Use (previously used land, use of remediated contaminated land);

- Ecology (land with low ecological value or minimal change in value, maintaining major ecological systems on the land, minimization of biodiversity impacts).

Pollution (leak detection systems, on-site treatment, local or renewable energy sources, light pollution design, avoid the use of ozone depletion and global warming substances) [3].

\section{Sick Buildings}

Sick buildings and cities have three main characteristics:

- First: Energy efficiency use and production.

- Second: Polluting the environment with gas emissions, fumes or liquid, and solid waste.

- Third: The use of chemicals in finishes.

\subsection{First: Energy Production}

\subsubsection{Depletion of Energy}

Over the past two decades, there has been a huge leap in architecture, resulting in the poor design of high-rise buildings and excessive use of glass in large windows. It is known that glass collects heat from sunlight falling on it, requiring a large amount of energy to cool the air.

The orientation of buildings, the method and materials of construction and interior activities, the height of ceilings, types, spaces and directions of windows and doors, climatic conditions, insulation, vacuum, poor ventilation and the use of various electrical appliances. All of this means draining a lot of energy.

\subsubsection{Production of Renewable Energy}

Energy is generally divided into two basic types: renewable energy and non-renewable energy. They can be replaced very slowly in nature. The renewable resources have a higher rate of degradation than their consumption, and non-renewable resources have a higher rate of consumption than their degradation. The renewable resources are environmentally friendly because of their low carbon footprint, unlike non-renewable resources with high carbon emissions that have serious environmental impacts. The major sources of renewable energy include solar, wind, hydro, bio-waste, hydrogen, and geothermal energy.

(Solar power plants use the energy contained in solar radiation and convert it into low voltage direct current. Solar systems, especially solar concentrating systems, are increasingly being used to help meeting energy needs) [4].

Environmental design is based on the optimal utilization of natural resources, particularly in local power generation, without relying on external energy, which 
may be costly or harmful to the environment. Solar Photovoltaic (PV) Cells are placed over the sloped ceilings on the sun-facing side, which produce electricity directly from the sunlight falling on them, as well as the scattered and reflected light from the neighboring surfaces to generate electricity, where it can work when the sky is cloudy. Electricity generated during the day can be stored in batteries to be used in darkness hours, which is made of silicon (sand), and its use does not harm the environment. (The study of the correlation of the dissimilar meteorological inputs, such as solar irradiance, atmospheric temperature, module temperature, wind speed and direction, and humidity, with PV power output, is important) (Figure 1) [5].

Water pipes can also be used by passing them deep into the ground to take advantage of their temperature, either by cooling or heating. A geothermal heat pump or ground source heat pump (GSHP) are characterized by concentrating naturally existing heat, rather than by producing heat through the combustion of fossil fuels. Technology is based on the fact that the earth (underground) remains a relatively constant temperature throughout the year, which is warmer than the outside air temperature during winter and cooler than the air in summer. (A GSHP system includes three principle components: 1) a ground connection subsystem; 2) heat pump subsystem; and 3) heat distribution subsystem. The GSHPs comprise a wide variety of systems that may use ground-water, ground, or surface water as heat sources or sinks). (In thermal radiation, heat is transferred by electromagnetic waves that travel in straight lines and can be reflected. The water temperatures are operated at very close to room temperature and, depending on the position of the piping, the system can take advantage of the thermal storage capacity of the building structure) (Figure 2) [6].

\subsubsection{Use Energy Efficiency}

\section{1) Thermal Insulation}

Insulation is one of the key elements of sustainable building design because the isolated building reduces the waste of energy by maintaining the heating in winter and coolness in summer, reducing carbon emissions associated with global climate change.

In the proposed model, the walls of the building are three directions (eastsouth-west) with a large thickness of $50 \mathrm{~cm}$ to $80 \mathrm{~cm}$ with a few openings. The walls consist of a $25-\mathrm{cm}$-thick clay layer that achieves some time delay in the thermal conveyor, and the 25 -cm-thick clay walls delay the heat by 10 hours. On the other hand, the walls of the concrete block, with a 20 -cm-thick, only delay the heat for five hours (Figure 3).

To increase thermal insulation, it is preferable to use well-dried clay, as well as adding a layer of cellulose insulation, which is one of the most environmentally friendly types of insulation. Cellulose is made from recycled cardboard, and other similar materials and produced in a loose form. It reduces the losses caused by fires due to the narrow space between the elements of the material, and it does not contain oxygen inside it. 


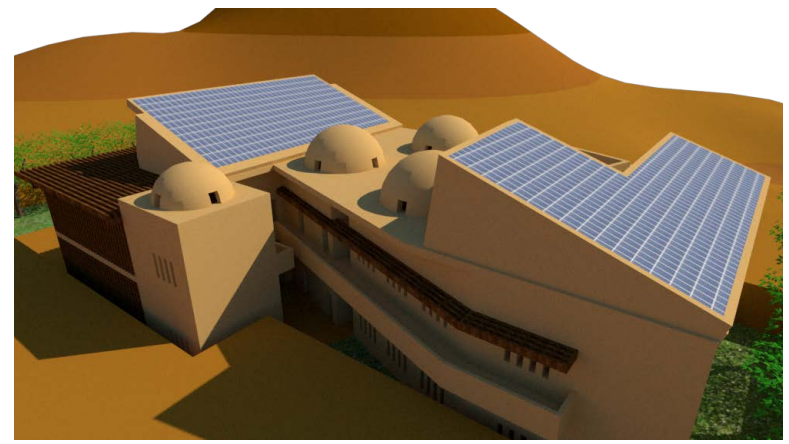

Figure 1. Solar photovoltaic (PV) cells (Author work).

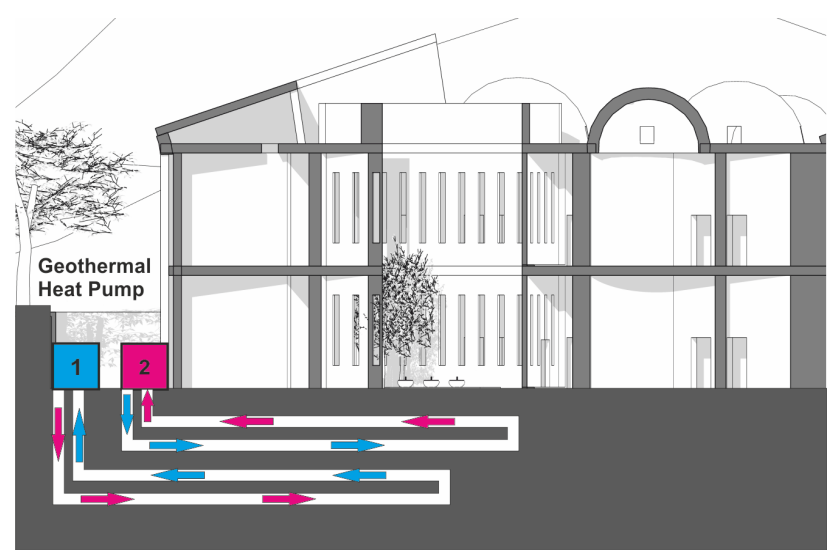

Figure 2. Geothermal heat pump (Author work).

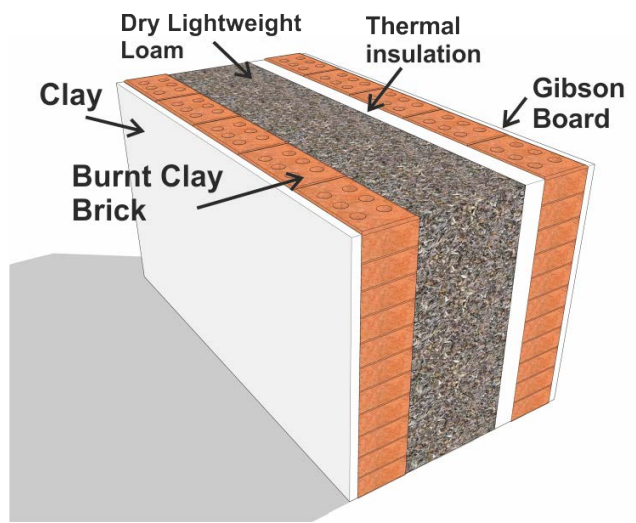

Figure 3. Section shows the details of the wall (Author work).

The clay layer is protected from the outside and the thermal insulation layer is protected from the inside with a layer of well-burned clay bricks, and the Gypsum board is placed as an interior finishing material, as it also used as a material to absorb moisture from the inner vacuum. For high-temperature insulation for silt surfaces, we can use boiling linseed oil, in addition, to paint the exterior walls with a layer of bitumen and lime-mortar.

Pyrogel rolls can also be used for high-temperature insulation, which is thermal insulation rolls up to $5 \mathrm{~mm}$ thick and withstand temperatures up to $650^{\circ} \mathrm{C}$, can. Therefore, it is the most effective thermal insulation material in the world 
recently, and it has five times better high-thermal performance than competing insulation products. It is also non-polluting material at all, because it contains few fibers, is easily removed, and contains no liquid water repellent fibers, which is porous allowing vapor to escape.

Water vapor: In moderate and cold climatic zones, the water vapor contained in indoor air diffuses through the walls to the exterior. If the air is cooled down in the walls and reaches its dew point, condensation occurs. This dampness reduces thermal insulation capacity and may lead to fungus growth. In such cases, it is important that this humidity is transported quickly by capillary action to the surface of the walls, where it can evaporate. Therefore, materials like loam with high capillarity are advantageous.

In order to reduce the danger of condensation in walls, vapor transmission resistance should be higher inside than outside. On the other hand, resistance to heat transfer should be higher outside than inside. Though the above principles normally suffice to inhibit the formation of condensation in walls, it is also possible to create a vapor barrier on the inside by utilizing paints or sheets [7].

\section{2) Natural lighting}

The distribution of windows and choosing their position can maximize the natural light, especially the reflected light while trying to avoid direct light. The allocation of some exposed spaces in the building, such as patios, allows the person to benefit from UV (Ultraviolet) rays. Therefore, it is important to study the different angles of the sun throughout the year and to study the proper orientation of the building.

As for the openings, due to the thickness of their glass, a large rate of the heat flowing into the building through infiltrates such openings through the exterior walls, which requires reducing their area not only to reduce the rate of thermal energy leaking into the building but also to try to reduce the strength of natural lighting in the interior spaces due to the intensity of the dazzle due to the clarity of the atmosphere most days of the year in addition to the characteristic of the earth's reflective surface (Figure 4).

As for industrial lighting inside the building: It is used in two cases: First, when natural lighting is insufficient in parts away from the windows, and the second when the sun sets and darkness falls. The choice of industrial lighting units is taken into account to give some kind of lighting that is as close as possible to natural light. The types of industrial lighting that save in the consumption of electric power, such as LED (light-emitting diodes) lamps, shall be selected. In some resorts, electricity is prohibited and rudimentary means of lighting are used, such as candles and oil bulbs.

\section{3) Shading}

The environmental design seeks to provide thermal comfort within the building, in the winter take into account the maximum benefit from thermal gain by solar radiation, while reducing heat loss from within the building. In summer the building needs to be cooled, taking into account the work to avoid solar radiation, and reduce heat gain and work to lose heat from inside the building and 


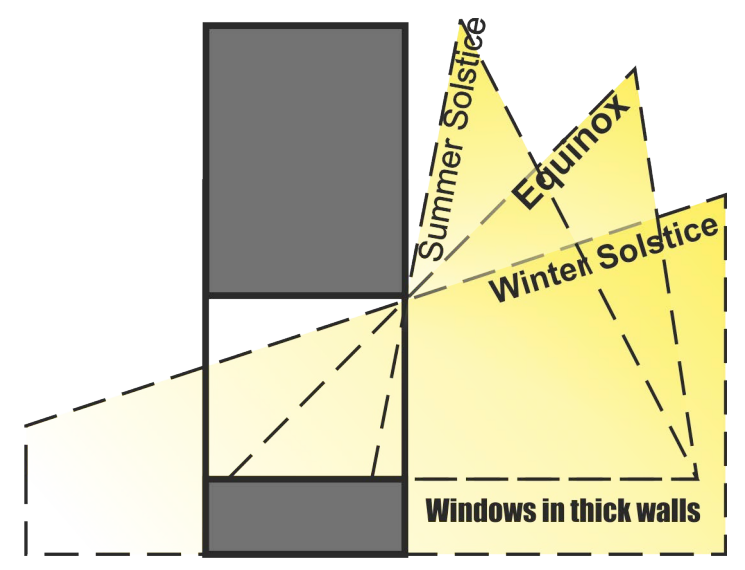

Figure 4. The large thickness of the walls prevents the entry of the summer sun through the windows but allows the entry of winter sun (Author work).

cooling its internal spaces by various architectural means using natural energy such as sun, wind, and rain.

Thermal radiation on walls and openings can be reduced by shading during the day. This shading is done using sun-blocking shades and studying the angle of inclination of solar radiation during the day. In particular, for the southern facades, the ceilings extending outward and other horizontal units prominent above the openings are useful in this case.

Solar power gain can be reduced through windows with shading, and orientation, Windows are opened in thick walls that allow ventilation and shading, making it particularly difficult to insulate windows compared to the ceiling and walls. Heat transfer through and around window glass deteriorates insulation properties. Therefore, external shading is more effective in reducing thermal gain than covering the interior windows (Figure 5 \& Figure 6).

\section{4) Building Orientation}

In Ancient Egypt, entrances of temples were oriented so that the sun rays reached the Holy of Holies in sunrise one day a year, called the day of the King's birth. The ancient Greeks built most of their buildings facing the east with large openings towards the south. This method of construction allows for the greatest amount of solar radiation in winter when the sun falls in the sky and reduces sun-exposed surfaces in the summer (Figure 7).

The horizontal projection of the proposed building is in the form of a rectangle. The building is oriented so that the short rib is in the direction of the south in order to reduce the area of the sun-exposed walls throughout the day. This orientation also allows solar cell power panels to be installed in the right direction of the sun, thus the wind catchers are directed to the direction of the prevailing wind to the north and northwest.

\section{5) Utilizing the potential of the soil by building underground}

The idea of underground construction depends on reducing the impact of climatic factors on the interior spaces, by taking advantage of the ground thermal storage capabilities called "Mass-impact Adaptation", and taking advantage 


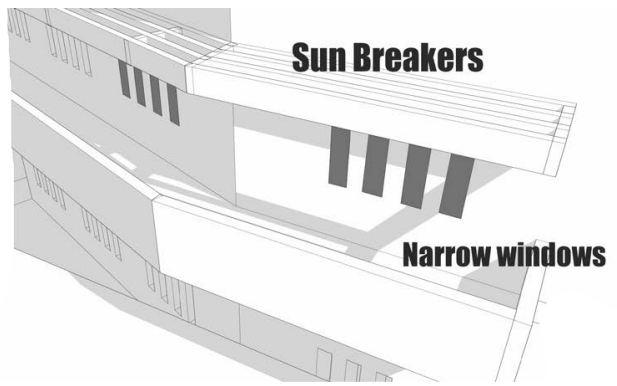

Figure 5. Wood Sun breakers in the northwest for cold air passage (Author work).

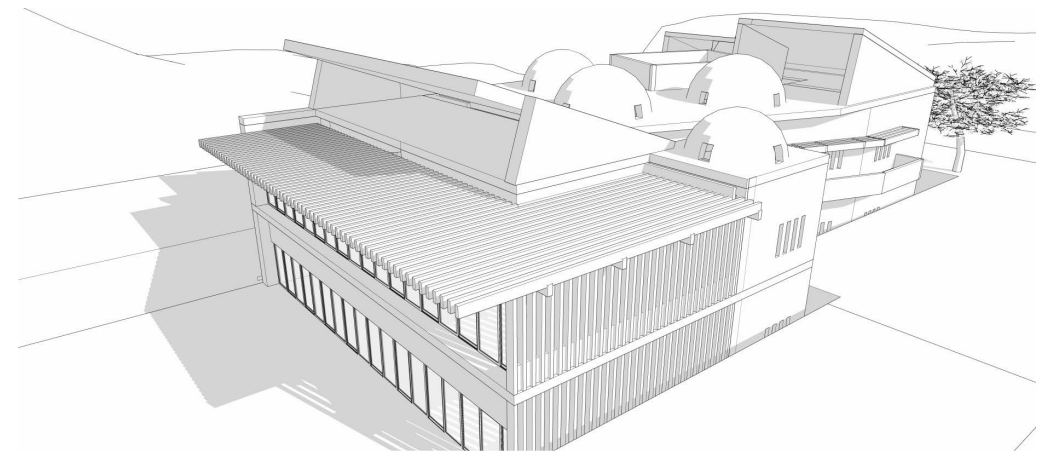

Figure 6. Sun breakers system is a highly efficient external shading system, which can also serve as a decorative part of the building (Author work).

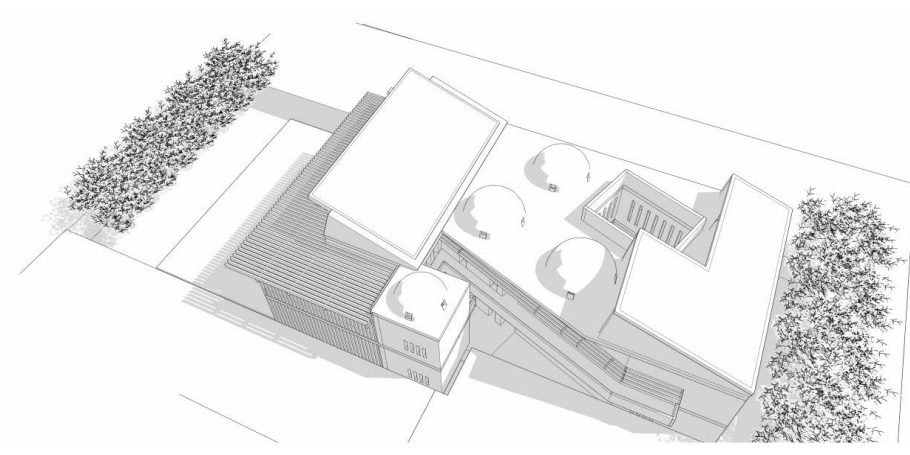

Figure 7. Building direction (Author work).

of the characteristics of the ground to reach thermal comfort in the basement vacuum. The ground floor is better in temperature from the upper floor, which is exposed to direct sunlight throughout the day, so in the morning, the ground floor and sometimes the basement is used, and in the evening, the upper floor is used.

The underground construction was built from three directions except for the northern direction, which was left open on a front yard, leaving an area of $1.5 \mathrm{~m}$ between the walls of the building and the ground to enter the air (Figure 8).

\subsection{Second: Polluting the Environment}

Waste poses a major threat to the environment. Hazardous industrial wastes, such as solvents, oil and grease remover, oils, radioactive materials, inks, dough 

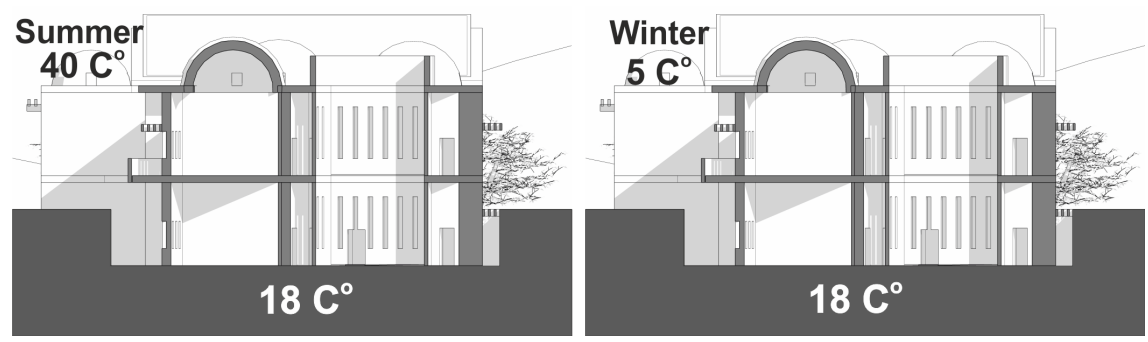

Figure 8. Taking advantage of the ground thermal storage capabilities called "Mass-impact Adaptation", and taking advantage of the characteristics of the ground to reach thermal comfort in the basement space (Author work).

deposits, acids, and alkalis, which arise from many sources that take different forms, whether liquid, solid, sludge or gases. Their greatest damage occurs when stored, transported and processed, or otherwise altered. It may seep into aquifers and reach living organisms.

We can identify three sources of internal pollution (Poor ventilation, People activities, External pollutants).

In modern buildings, it is noted that the buildings are tightly closed and their ceiling is low, and windows are closed with large areas of glass, resulting in a decrease in the amount of fresh air reaching the inside of the building. Also, there is no doubt that the behaviors of the people in their lives inside the dwellings are a source of internal pollution, such as the use of appliances, including stoves, air conditioners, washing machines, fans, and vacuum cleaners, and other behaviors such as smoking and personal hygiene.

It is proven that half of the dust suspended in the atmosphere may seep into buildings, and its danger is that they contain toxic lead from car exhausts. Reports have shown that the concentration of lead in the air inside buildings is twice as high as in the outside air.

\subsubsection{The Most Important Indoor Air Pollutants}

- Toxic gases: Toxic gases, especially carbon monoxide, may pose a risk to human health when emitted from heating devices. This emission is accompanied by oxygen depletion, high concentrations of carbon monoxide gas that cause physiological changes in the human body that may lead to death. There are other toxic gases emitted from heating devices such as nitrogen oxide.

- Formaldehyde: A lot of building materials and wood contain formaldehyde. Plywood, compressed wood, and floor tiles are made from urea-formaldehyde. Formaldehyde emission increases indoors as temperatures and the humidity rise. Gases emitted from formaldehyde cause severe health damage to the people.

- Radon: Radon is a radioactive gas because it comes from the uranium element in the soil, seawater, and well water, but it is increasingly concentrated indoors, such as old and poorly ventilated buildings. In the United States, about 20,000 people die every year from lung cancer caused by inhaling ra- 
don.

- Air conditioners: Polluting and invisible gases, as well as dust containing in organic matter, mold or fungus are emitted from air conditioners and central heating, such organic matters represent an environment suitable for the growth of fungi and microbes.

- Smoking: Smoking of all kinds causes serious damage to the respiratory system.

- Microparticles: Solid particles with different diameters are released into the air from multiple sources, including metal dust, fiber and asbestos. Micro-particle pollution occurs indoors, as a result of non-regeneration of air. Such particles are emitted from furniture and building materials, such as poor types of paints on the walls.

\subsubsection{Interior Health Environment and Pollution Control}

It is worth mentioning that it is possible to protect the environment and reduce the effects of harmful wastes by recycling and reducing the amount of waste consumed, in addition to treating waste by chemical methods such as ion exchange, precipitation, oxidation or thermal method that destroys the toxic molecules in waste by exposing them to high temperatures using special devices, such as rotary kilns, by the physical method, including sedimentation, evaporation, hardening, flotation, and filtration, or by the biological processing method used for some organic waste.

Some green lodges prohibit smoking, chemical fragrances, insect repellent, and shaving products, reduce perfumes and use locally supplied organic materials, and emphasize leaving the shoe at the door or putting it in special "neoprene" socks, and leaving all special personal care products at home. Only organic products provided by the resort are permitted.

Some resorts also prohibit the use of electricity or any electrical or mechanical equipment, or use gasoline-driven cars and replace them with electric cars.

Air inhalation, which contains many pollutants, has significant health damage. The problem of indoor air pollution increases with the increasing use of building materials, synthetic finishes and various building chemicals. Non-natural materials contribute to the concentration of pollutants in the air and create an unhealthy indoor environment. In addition, modern buildings are tightly closed so as not to allow any air leakage in order to control heating or cooling processes, thus becoming poorly ventilated, helping to increase the concentration of pollutants.

To set up a waste management program. Your objectives should be too, wherever possible:

Reduce: The best way to improve waste management is to create as little waste as possible by not purchasing it to begin with.

Recover: You need to set up systems to collect and sort the waste so that it can be reused or recycled.

Reuse: Consideration will need to be given to where certain items can be 
reused, or whether they can be sold or donated to organizations outside the hotel that can reuse them.

Recycle: Many hotels, restaurants and tourism establishments already have some system in place for sorting and collecting everyday waste items such as bottles, cans, cardboard and paper for reuse or recycling. Have you considered all the waste you generate and what else might be recycled? What happens to your used batteries, plastic bottles, wine corks, bathroom amenities or cooking oil for example [8]?

\subsubsection{Natural Ventilation}

Good ventilation of the building is one of the most important factors in overcoming the concentration of pollutants. Therefore, it is important to direct the building openings to the direction of the prevailing wind, examining the locations and size of the air inlet and outlet to create a good airflow.

Constructing a courtyard in the center of the building works to cool and move the air in it by shading trees, and then moves to the neighboring rooms. The openings of the walls overlooking the courtyard are narrow openings, allowing air to pass from the courtyard to the interior spaces, preventing the entry of sunlight radiation.

The height of the courtyard wall is large, providing the largest area of shade and providing a water element to humidify the air. Part of the courtyard can be roofed to protect against sandstorms and extreme heat. The ceiling of the courtyard provides the possibility of maintaining the coolness gained at night (Figure $9(a))$.

The use of domed roofs increases airflow passing over their curved surfaces, which reduces the temperature of such roofs. In the interior spaces, it pulls the hot air upwards and takes it out through the openings in the sides of the dome.

Sloped roofs are also used in the direction of the south towards the sun, and formed a deviation space from the north and it forms a roof insulator from the direct sun heat, and at the same time, it forms a wind catcher to receive cold winds (Windcatcher). Such windcatcher, due to the breadth of its opening from the front and its narrowness sharply from the rear, can collect and increase the speed of the wind that passes through a narrow vertical space between the interior walls of the building.

And increase the speed of air coming out through the openings under the walls of the interior spaces, which is formed on the floor of the rooms, and because of its weight compared to the lightweight hot air, it pushes the hot air up, where the dome is located, which increases the airspeed, then it comes out from the opening of the dome, or out of the window openings in the walls of the rooms (Figure $9(\mathrm{~b})$ ).

Pottery or terracotta pots (burned clay) filled with water may be placed at the top of the windcatcher to add moisture to the indoor air (hot dry climate). Grids of wire with the straw of palm fronds may also be placed to purify the air from dust and suspensions. Pieces of coal may also be placed to absorb odors and 


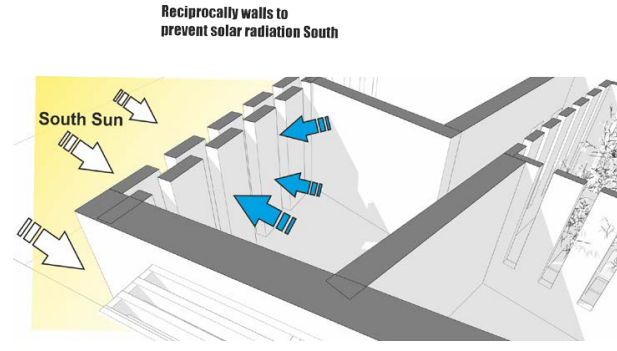

(a)

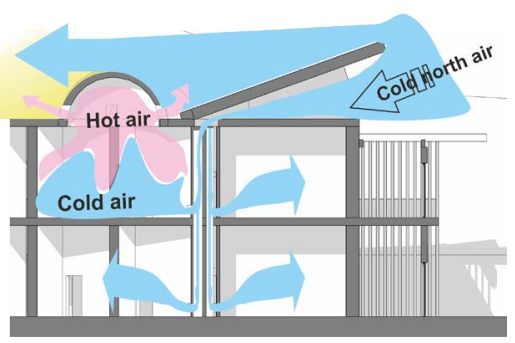

(b)

Figure 9. (a) \& (b) The movement of air through the windcatcher into the building and the courtyard and out of the windows.

moisture (hot, humid climate) and photovoltaic cells are placed above the sloping roofs-windcatcher-on the side facing the sun, to exploit direct sunlight.

\subsubsection{Sound}

Like harmful wastes, it has tangible effects on the mental and physical health of the human being. Acceptable or beautiful sounds have good psychological effects and on the contrary, the noise has harmful effects. Studies have confirmed the seriousness of noise and loud noises on human mental and physical health as well.

\section{There are three main sources of noise inside buildings:}

The first of which is the noise coming from outside the building, resulting from transportation, cars or work-shops. Such noise is carried by air and enters the building through open windows and doors, and they should be avoided by choosing the location of the lodge away from it, preventing cars from entering or near the lodge site, planting large leaf trees in the direction of noise, and reducing the building's openings in that direction.

The second source of noise is the result of the vibrations of some electrical appliances, which must be in isolated places away from the guest's residence (Figure 10).

The third source of noise results from the transmission of noise through the walls and floors from the neighboring spaces. The thicker walls of natural materials such as stone and clay are good at preventing noise transmission.

As for flooring, it is preferred to use floors, finishes or sound-absorbing finishes from natural materials such as straw and palm trees, or carpets made from goat and sheep fur (Table 1).

\subsubsection{Water}

"Greywater systems" is the process of wastewater reuse, which is the result of the use of bathrooms, showers, and kitchens. Such a process has a great effect in reducing water consumption in buildings, where they are collected in a ground tank, treated and filtered using sand, gravel, and biological filters, then reused for garden irrigation or used again in the toilet flushing.

Rainwater harvesting is also an important process in reducing water consumption. In some dry areas, it falls in the form of heavy rain for a short time. 


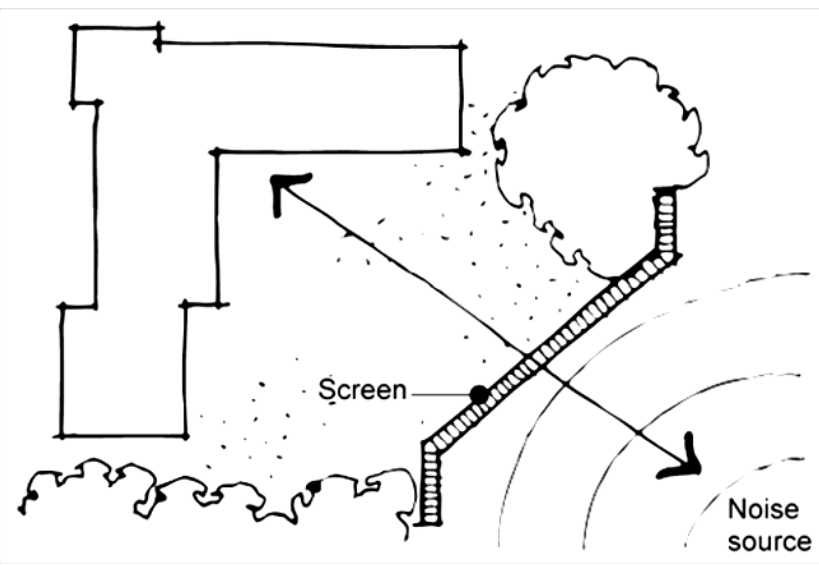

Figure 10. Place a screen between dwelling and noise source [9].

Table 1. Sound levels and their perception [9].

\begin{tabular}{ccc}
\hline $\begin{array}{c}\text { Sound level } \\
(\mathrm{dB})\end{array}$ & $\begin{array}{c}\text { Approximate loudness relative } \\
\text { to ordinary conversation }\end{array}$ & Perception example \\
\hline 0 & Don't hear anything & Threshold of hearing \\
10 & $1 / 32$ as loud & Very faint normal breathing \\
20 & $1 / 16$ as loud & Quiet room \\
30 & $1 / 8$ as loud & Quiet conversation/quiet office interior \\
40 & $1 / 4$ as loud & Moderate quiet office/quiet rural area \\
50 & $1 / 2$ as loud & Quiet suburban area/dishwasher in next room \\
60 & Ordinary conversation & Average office/ordinary conversation \\
70 & Twice as loud & Loud busy street/vacuum cleaner at $3 \mathrm{~m}$ \\
80 & 4 times as loud & Noisy office/passing car at $3 \mathrm{~m}$ \\
90 & 8 times as loud & Very loud heavy traffic/passing bus or truck at $3 \mathrm{~m}$ \\
100 & 16 times as loud & Loud car horn/passing subway train at $3 \mathrm{~m}$ \\
110 & 32 times as loud & Pop group/night club with band playing \\
120 & 64 times as loud & Extreme; jet take-off at $100 \mathrm{~m}$ \\
\hline
\end{tabular}

Rainwater is collected and stored in different ways, the most famous of which are wells and ground reservoirs, which can be used in bathrooms, gardens irrigation, and car wash. It can also be used in swimming pools and water fountains after ensuring that it is free of contaminants.

(Ideally, the system should be able to treat all of the hotel's wastewater and generate effluent of sufficiently high quality for reuse for irrigation. Greywater systems enable up to 50 percent of wastewater to be returned to the hotel after treatment for toilet flushing. Because of the separate pipe-work involved, greywater systems are expensive to install and chemical treatment of the recycled water is necessary for health and safety reasons. They are therefore best designed into the building at the outset, although increasingly hotels are choosing to retrofit them because of the savings to be made. Payback time is difficult to calcu- 
late, as it will depend on the type of systems installed and the relative cost of the potable water to that of the reuse water. The payback can be anything from two to fifteen years depending on the cost of water at your location) [10].

\subsubsection{Plants}

The urban green structure reduces pollution, serves as a filter to purify the air, increases oxygen emission in the atmosphere, and helps reduce the air temperature in urban areas. Thus, it reduces the temperature inside buildings and reduces the energy consumption used in refrigeration. Solar radiation falling on the green mass is divided into three parts; the first part is absorbed and transmitted, the second part is dispersed in the atmosphere in the form of latent and sensible heat, and the third part is used in plants in the process of food conversion through photosynthesis. Plants convert solar energy into chemical energy, especially by absorbing the hottest visual sunlight. The green cover emits less infrared radiation than earth or industrial materials, thereby reducing the rate of thermal radiation of the environment.

Therefore, in order to protect the outer surfaces from the sun on summer days, it is necessary to plant plants beside the southern wall and on the roof of the building, choose deciduous trees at the source of solar radiation, uncover the walls on winter days after the fall of leaves when the sun is needed and create a rooftop garden, as the shade of green cover contributes to the cooling buildings, reduce its internal temperature and ambient temperature by using it on the sides of the buildings.

Surrounding buildings with groups of evergreen trees and shrubs achieve two main objectives:

First: Intercepting sunlight before reaching the building walls with the shading of such walls.

Second: This green barrier works as a filter to purify the air from the dust and sand particles that fill the atmosphere, especially during sandstorms that blow frequently in these areas.

The role of such trees is not only to protect buildings from sunlight falling on the exterior elements of the building, but also helps to raise the humidity in the hot humid climate area, because of its ability to absorb some thermal energy in hot air passing through it on the way to the buildings, resulting in the evaporation process, as well as the rise in humidity. It also softens the air temperature that reaches these buildings.

\subsection{Third: The Use of Chemicals in Finishes}

As the urbanization circle expands, the building industry has evolved in a manner that increases its closure in order to preserve energy. Indoor gas emission rates have increased, causing diseases, illnesses, and complications in many people. The specialists analyzed air samples and the components of the buildings. Laboratory tests indicated contamination in the interior of such buildings. The sources of internal pollution varied, including, but not limited to, chemical, 
physical and microbial.

\subsubsection{Use of Eco-Friendly Materials}

In the past, the building was based on the use of natural materials such as stone, clay, wood, and straw. In the present era, it was found that such materials had positive environmental-supportive effects in terms of their non-impact on global warming. Such material is suitable for the environmental conditions of the place, can be recycled and have a positive impact on public health. However, because of the fear of the depletion of such natural resources of materials, researchers have resorted to producing sustainable building materials, by manufacturing building materials that have little impact on global warming and reducing the amount of waste.

Local materials provide protection from climatic conditions. Clay or adobe and stone, as well as wood, palm fronds, and bamboo, are considered the best natural building materials that can provide thermal insulation of the building, reduce the depletion of vital natural resources, and carbon emissions. Mud, stone, and wood would have been widely used in many buildings throughout the ages, and if built with large thickness, it helps to provide good thermal insulation to the interior spaces of the building. Even in extremely cold areas such as the Arctic, large-thickness blocks of snow have been used to build houses and insulate interior spaces.

A number of substances found within the fabric of hotel buildings or that are used as part of the hotel operation pose potential hazards to human health, biodiversity, and the environment. They must be handled, stored and disposed of carefully and replaced with less hazardous alternatives where possible. This approach should include phasing out the use of man-made chemicals that do not naturally degrade in nature and thus systematically increase in concentration over time.

A hazardous material is any substance that can cause injury, impairment to health or death to living organisms, or which can damage the environment through, for example being toxic, flammable, explosive, corrosive or infectious. In most countries, there are legal requirements governing the responsible use, storage and disposal of hazardous materials. There are also international agreements covering the use of substances that pose a hazard to health and the environment. These include the Stockholm Convention, a global treaty to protect human health and the environment from persistent organic pollutants (POPs). POPs are chemicals that remain intact in the environment for long periods, become widely distributed geographically, accumulate in the fatty tissue of living organisms and are toxic to humans and wildlife. The European Union has passed numerous directives and regulations to avoid the dissemination and restrict the use of hazardous substances, the best known to be the Restriction of Hazardous Substances Directive and the Registration, Evaluation, Authorization and Restriction of Chemicals (REACH) directive which came into force in June 2007. To complement REACH, the United Nations has proposed new regula- 
tion, the Globally Harmonized System of Classification and Labelling of Chemicals (GHS), which will require enterprises to use standardized symbols and phrases on the packaging and on Safety Data Sheets (SDS) to inform users about hazardous chemicals [11].

\subsubsection{Criteria Used for Identifying-Friendly Materials}

1) Natural, copious, or renewable.

2) Manufactured from efficient resources, where manufacturing is done through industrial processes that consume small amounts of energy, do not produce residues, and reduce greenhouse gases.

3) Local availability of building materials, components, and systems, which saves the energy consumption required for transportation to the construction site.

4) Reuse or recyclability until the end of its life.

5) High endurance, like traditional materials with longer life expectations.

6) Non-toxic or low-toxic and does not generate toxic substances.

7) Low emissions of Volatile organic compounds (VOCs).

8) Moisture resistant.

9) Improving indoor air quality by preventing air pollutants.

10) Reduce maintenance and replacement costs over the life of the building.

11) Reduce the costs of changing the shapes of the spaces.

12) Unlimited flexibility in design.

\subsubsection{Eco-Friendly Building Materials}

\section{1) Stone Buildings}

In terms of embodied energy and embodied carbon such as many studies comparing natural stone with other building materials have demonstrated the total energy inputs consumed throughout a stone construction life cycle and the carbon footprints of the entire process are lower than those of other building materials, such as concrete, bricks, and concrete block In terms of energy efficiency, stone masonry can play an important role by virtue of its high thermal inertia, which is the property that enables building materials to slow-ly absorb, store, and later release significant amounts of heat, contributing to indoor temperature stabilization against outdoor variations. The most energy is saved in summer, in geographical zones in which significant reversals in heat flow occur within a wall between night and day: the heat absorbed during the day by the mass of the wall can be cooled by natural ventilation during the night. Masonry buildings are green and a healthy solution also because they are not harmful. There are no toxic materials used in processing, nor are there direct greenhouse gas emissions during processing. Masonry building materials do not contain [12].

Building and decorative stone-stone used for its resistance to weather or its aesthetic appeal—walls and decorative purposes. Buildings, walls, and paving slabs.

Aggregates-stone used for its strong physical properties—crushed and sorted 
into various sizes for use in concrete, coated with bitumen to make asphalt or used "dry" as bulk fill in construction. Mostly used in roads, concrete, and building products.

Industrial purposes-limestone can be used for its chemical (mainly alkaline) properties as calcium carbonate $\left(\mathrm{CaCO}_{3}\right)$ in the farming and manufacturing industry.

Lime burning (calcining)-limestone when heated to a high-temperature break down into lime (calcium oxide) and carbon dioxide gas. It can then be used as a more powerful alkali than limestone or used as a cement with sand, to make mortar, or as a soil improver in agriculture.

Cement-if limestone (or its variety chalk) is mixed with clay or sandstone before firing, it can produce Portland cement which when mixed with aggregate makes concrete [13].

\section{2) Mud buildings}

Mud is a major building material in many parts of the world. Some of the mud buildings lasted for a thousand year. It is known that one-third of the world's population lives in buildings, at least part of which has been built of mud, and the techniques used to build them have diversified. Such buildings have been constructed using raw mud bricks, bars, straws, plaster, and other materials. An entire number of communities have been constructed and preserved based on ancestral skills, representing $20 \%$ of World Heritage Sites that are admired by the world and are inscribed on the UNESCO World Heritage List.

Nubian in Aswan, Egypt, tried to preserve his heritage so as not to lose it over time. The fame of Nubian house is global, inspiring renovation lovers with its design, from the late Egyptian architect Hassan Fathy, who drew some of his ideas from this model to the famous American Architect Michael Graves, the designer of The Egyptian red sea city, El Gouna, based on the Nubian style.

Germany used straw and mud in buildings as being eco-friendly materials, to reduce costs and save energy. Germany is the first European country to prove that the use of straw as a building material provides better insulation than modern building materials.

Many researchers analyzed the mud and found that it consists of $34 \%$ alumina, $50 \%$ silica, $6 \%$ lime and magnesium, $8 \%$ iron oxide, $2 \%$ organic matter, pure mud, which called clay, contains $46.5 \%$ silica, $39.5 \%$ alumina and $14 \%$ water. Each particle of mud consists of compact layers of such materials. The diameter of the soft mud particles $0.002 \mathrm{~mm}$, while the diameter of the coarse mud particle ranges from 0.02 to $0.002 \mathrm{~mm}$. The mud has two conditions: when it is wet it becomes flexible and we can form it according to the de-sired models, and when exposed to the sun or burned at high temperature and the water evaporate it becomes solid as rocks.

(Plasticity is the property of a material to be deformed under stress and to retain the new shape after the stress is removed. It is a characteristic property of clays because other minerals which may be of clay size are not plastic. The na- 
ture of plasticity is related to the water molecules which are adsorbed on the clay mineral surfaces forming a rigid film with a certain order, which links together clay particles (Grimshaw, 1971). The clay particles form coherent networks, which can deform and retain their shape after the stress is removed) [14].

What distinguishes mud building from cement is durability and impact resistance. If the concrete wall is hit or in the event of an earthquake, the concrete wall falls as a single block while the mud building is affected by only scratches. The mud is cold and this is suitable for the local environment. The shelf life of mud buildings is longer than concrete buildings.

The implementation of mud buildings is done in different ways, including "direct formation" and "this method is widespread in several regions such as Africa, Yemen, and France. Another common method is "mud bricks" and the third method is "PISE", which is used in Denmark, Morocco, and Peru, while in Syria it is used only for the construction of farms and houses.

The mud is one of the best environmental materials and does not constitute any pollution of the environment during manufacturing, implementation or modification or in the event of demolition and reconstruction of the building or even if it is abandoned and collapsed, as it comes from the land and returns to it.

\subsubsection{Use Eco-Friendly and Sustainable Materials in the Interior Finishing Works}

The handicraft product has its own elegance and precious value, as the traditional handicraft product shows goodness and originality, as it represents for many to get out of the hustle and bustle of modern contemporary life.

\section{1) wicker}

Wicker" is to collect palm frond leaves, braid them by hand and tie them to rice straw, until the desired shape is finished, then left in the sun to dry and take the white color, and can be colored in many colors to make an aesthetic shape. The fronds are divided into three degrees and are used to manufacture decorative utensils, laundry utensils, mats, benches, tables, handbags and cages used to store vegetables and fruit.

It is a simple rural industry that has been a source of livelihood for thousands of families, where palms and its trunks are used. It is an inexpensive raw material industry and does not include any industrial or chemical materials. Palm branches are used to make floor mats and bamboo floors that share similar properties with wood. Bamboo is sustainable and made from natural plants that grow to maturity within five years, are durable, easy to maintain, clean, and very light.

\section{2) Cork}

The Cork comes from a type of oak tree, after carefully removing the outer bark without damaging the tree. The cork used in the floors is the remnant of the cork plug industry. The product is not only harvested sustainably, but it is also recycled material. The cork floors have some flexibility, making them comfortable to stand and walk. The material consists of cells that restore their nature 
after walking on them. The cork floor absorbs sound and resists mold. It is also warmer in its texture than other floors and is characterized by lower chemical emissions.

\section{3) Recycled glass}

Recycled glass can be melted down into different forms of glass. When glass arrives in the recycling facility, they are broken and crushed up into tiny pieces, then prepared to be mixed with raw materials like sand, soda, and limestone. The glass pieces are melted and molded into a new glass piece.

The Glass produced from recycled glass is melted at lower temperatures thus lowering energy requirements for production. Recycling glass also reduces the amount of glass waste.

Glass from food and beverage containers can are $100 \%$ recyclable.

Glass can also be easily upcycled or reused in a creative way. Some companies are even using recycled glass bottles to create mosaic-style countertops.

After recycling, the used glass can be converted into glass tiles. This renewable source turns into a great choice for floors as well as bathroom and kitchen walls. Glass has similar benefits to other eco-friendly materials. It is not absorbed and will not be molded in moist environments.

\section{4) Recycled Paper}

Recycling paper products can have a large impact on the environment as it reduces the amount of paper that comes directly from trees. This is enough to significantly impact the number of greenhouse gases in the atmosphere and keep paper out of our landfills. Some companies are opting for chlorine-free bleach in order to reduce their environmental impact. Most recycling programs allow you to recycled most paper, including newspaper, white office paper. There are many eco-friendly paper products that are made from recycled paper.

\section{5) Sheep's Wool}

Sheep's wool can be regrown quickly. After shearing, sheep inherently produce a new crop. Clothing manufacturers have long-known the insulating properties of wool. The same insulating features can make sheep wool an energy-efficient insulator in walls, ceilings, and attics. Sheep Wool Insulation is totally natural, environmentally friendly, and quick and easy to install. Wool insulation and other eco-friendly products appeal to the growing numbers of homeowners and buyers looking for green buildings with an excellent energy rating. It is a favorite for most lodges. It gives a feeling of comfort in walking and sits on it. Wool is a natural resource that is woven into a thread and can be dyed in any color imaginable and then woven to create a carpet. It is one of the first materials used to cover floors, and it is extremely durable and can last for centuries, just like other natural materials used in carpeting, such as cotton and linen.

\section{6) Leather}

It is also a wonderful material that can be used as a floor. It is derived from the bulk of cowhide, it gives a warm feeling and is ideal for bedrooms, and small areas. It is very durable. The old and dilapidated leather acquires its own charac- 
ter that extends for many coming years.

\section{7) Plant-Based Polyurethane Rigid Foam}

It's made from kelp, help rigid foam is often used as an insulation material in building. Because it is rigid - and relatively immovable - it can be used in insulation. It offers protection against mold and pests, as well as sound insulation and heat resistance.

\section{8) Terracotta}

Terracotta is one of the oldest crafts known to man. Terracotta is made of clay and was dried in the air and sun, and then burned to give the color red or black according to the oxides of the minerals found in clay material. It was decorated and polished before or after the burning, and was colored with metal oxides.

Terracotta is used in making pots to preserve food such as jars, cooking utensils, including pot, twine, cups, jugs and dishes, pots for water preservation and cooling, vases, planting pots and floor and wall cladding tiles. It is used in the form of tiles for cladding floors, walls and making sewage pipes.

\section{9) Bioplastic Compostable}

Bioplastics are materials made from sugar cane fibers, corn, and potato starch. They are eco-friendly alternatives to plastics which can take hundreds of years to biodegrade in the environment.

Since bioplastics are generated from natural sources, they will break down naturally instead of producing more plastic waste into the environment.

\section{0) Cotton and linen}

All the fabrics we wear are made of fiber, but the nature of those fibers varies between natural fiber and industrial fibers, natural fibers are cotton, linen, wool and natural silk, while industrial fibers are industrial silk, polyester, and nylon.

(Sustainable Textile Production (STeP) by OEKO-TEX ${ }^{\circledast}$ is a certification system for brands, retail companies, and manufacturers from the textile chain who want to communicate their achievements regarding sustainable manufacturing processes to the public in a transparent, credible and clear manner) [15].

The fabrics that get the eco tex mark are divided from 1:4 according to the nature of the contact between the product and the human body, knowing that not only the processed materials that get the mark but all the materials that enter the production of bristles, fibers, and fabrics.

Industrial fabrics or fibers depend on their composition on chemicals. Such fibers are prepared from the simple elements found in coal and petroleum. The level of absorption of moisture and sweat is low, so it is not used in hot, flammable atmospheres that prevent the absorption of sweat.

Natural fabrics are characterized by the fact that they do not cause any discomfort to the body as they absorb sweat, comfortable in hot and cold weather. Cotton is characterized by a lack of electrical charges compared to other materials.

Linen textiles, which vary between thick and thin linen and some types of lace, is one of the strongest natural fibers where its durability is equivalent to twice or 
three of cotton durability. Linen is also one of the oldest fabrics used by pharaohs in the textile industry. Linen fabrics are used in clothing and thicker fabrics are used in upholstery and fabrics and making of some types of furnishings such as mattresses and sheets (Figure 11).

\section{1) Paints}

(Volatile organic compounds (VOCs) are gases emitted from different solids or liquids, many of which have short-term and long-term negative health effects) [16]. Lead is added to the paint to speed up its dryness, increase its durability, retain it fresh, and resist moisture that causes corrosion. Lead paint is still used in the industry. Lead is a toxic metal that can damage neuronal communication and cause disruption of the blood-brain barrier.

Solvents in traditional paint often contain high volumes of volatile organic compounds (VOCs).

Resin, which makes the paint stick to the walls and holds together, and additives that enhance the effectiveness of other ingredients, colored dyes, and industrial solvents also have a significant negative effect on human health.

Paints with low-volume volatile organic compounds improve indoor air quality and include the beneficial properties of these paints: less odor, clean air, safer technology, excellent durability and washable.

Lead processing products are also available. Ecological bonds can chemically change lead to less intrusive and thus have a lighter impact on the environment. Choosing natural paints may be the easiest way to avoid chemicals entering buildings and obtain the same result and efficacy. The main ingredients in these paints include linseed oil, soil and mineral dyes such as yellow ochre and turpentine, a natural distilled solvent from pine trees, which is biodegradable and renewable, and limonene natural solvent extracted from citrus, as well as from chalk.

In recent years, natural paints have witnessed a remarkable boom and demand after they have proven their effectiveness and quality. Such paints also allow moisture to pass even though they are waterproof.

Natural oils also form a protective material because their nourishing effect on the walls is similar to that of plants and trees. When used on new wood, it seeps

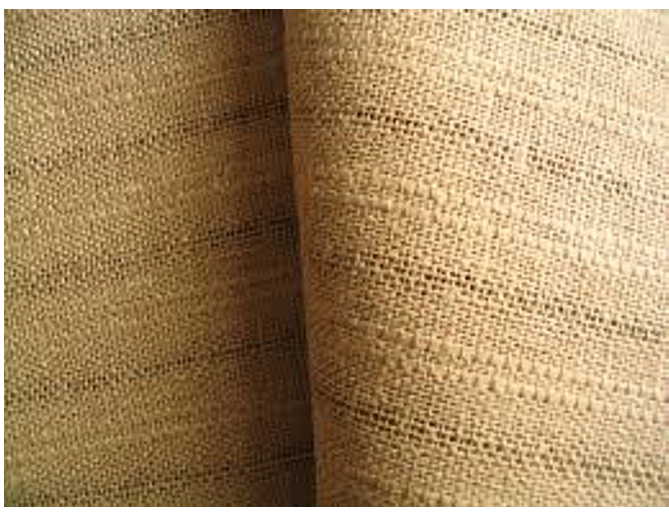

Figure 11. Linen cotton, linen fabric [17]. 
into the wood fibers, providing long-term protection and replenishing old wood. Flaxseed oil keeps the paint flexible and protects it from cracking.

\section{2) Reused Wood}

Instead of purchasing lodges items such as flooring and furniture which would be produced from virgin timber, opt for reclaimed wood as an eco-friendly alternative. This option will save energy, eliminate landfill burning, and reduce timber harvesting keeping more trees. Old wood can be reclaimed from many sources, such as old shipping pallets, unwanted furniture, and razed buildings.

\subsubsection{Sustainable and Eco-Friendly Furniture}

All materials have an effect on the air, which may not necessarily be toxic, Studies have shown that the air quality inside buildings is worse than that of the outside. There are some good ways to help maintain the quality of the interior air, especially with regard to furniture that must be untreated or treated with natural materials such as natural wood paint, naturally tanned leather, and natural cotton. The other way to avoid toxic substances is to buy original old furniture, or used furniture that may have exhausted its ability to emit toxic substances into the air.

(Eco-friendly furniture offers many benefits. It's great for health because of the low chemical and toxin content. It also reduces the growth of landfills, which improves indoor and outdoor air quality. Additionally, this type of furniture helps keep the planet green and reduces the consumption of nonrenewable resources. Plus, you'll often save money on green furniture over the alternatives. Any piece of furniture made from recycled materials can bear the sustainable label. Used metal, textiles, and timber, for instance, can all help the environment. In fact, if you pick up a vintage chair at a flea market, you're technically buying a sustainable product because it might otherwise wind up in a landfill) [18].

Sustainable furniture should be easy to repair, disassemble, reassemble and recycled at the end of the use period. The furniture industry must maintain nature's biological balance and support ecosystems. This does not mean that the durability element in furniture can be abandoned because even recyclable materials require energy and resources for reprocessing and replacement (Figure 12).

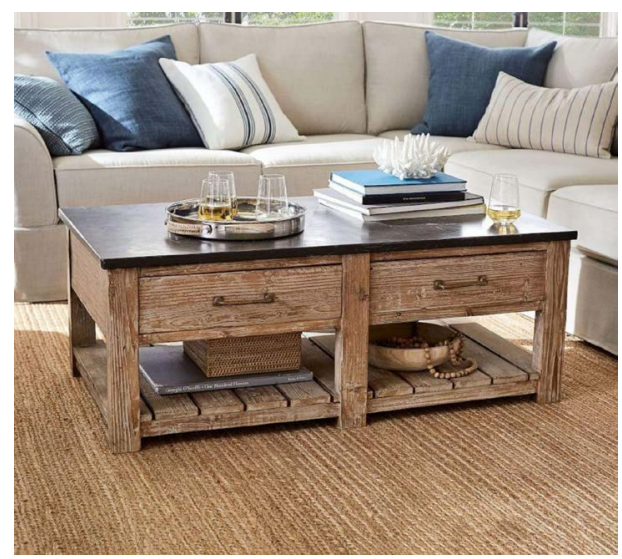

Figure 12. Recycled Wood furniture [19]. 


\section{Results}

1) The optimal utilization of natural resources, especially in local power generation without relying on external energy that may be materially expensive or harmful to the environment. Solar Photovoltaic (PV) Cells that produce electricity directly from sunlight are the most appropriate way to generate clean and non-polluting energy. Photovoltaic cells can be placed on sloping surfaces on the sun-facing side to exploit direct light as well as scattered light reflected from adjacent surfaces to generate electricity (Figure 13).

2) In terms of energy efficiency, developing insulation is more effective than expensive heating techniques. The use of the appropriate materials in terms of insulation properties is very important. There is also a need to use sustainable materials, i.e. materials with low energy and carbon embodiment.

3) The ecotourism tries to preserve the original environment and does not use any techniques that disturb the environmental balance and biodiversity of the site, ensuring the preservation of the environment and the sustainability of its resources.

4) The process of wastewater reuse called greywater. It has a significant effect on reducing water consumption in buildings, and also energy.

5) The eco-climate design seeks to provide thermal comfort inside the building. And in terms of energy efficiency, take advantage of the temperature of the earth, either by cooling or heating, which is warmer than the temperature of the outdoor air during the winter and cooler than the air in the summer. Orient the building in order to reduce the area of sun-exposed walls throughout the day. It also allows wind catchments to be directed to the prevailing wind direction (Figure 13).

6) Good ventilation of the building is one of the most important factors to reduce power consumption and overcome the concentration of pollutants in it. Therefore, it is important to direct the building openings to the direction of the prevailing wind, examining the locations and size of the air inlet and outlet to

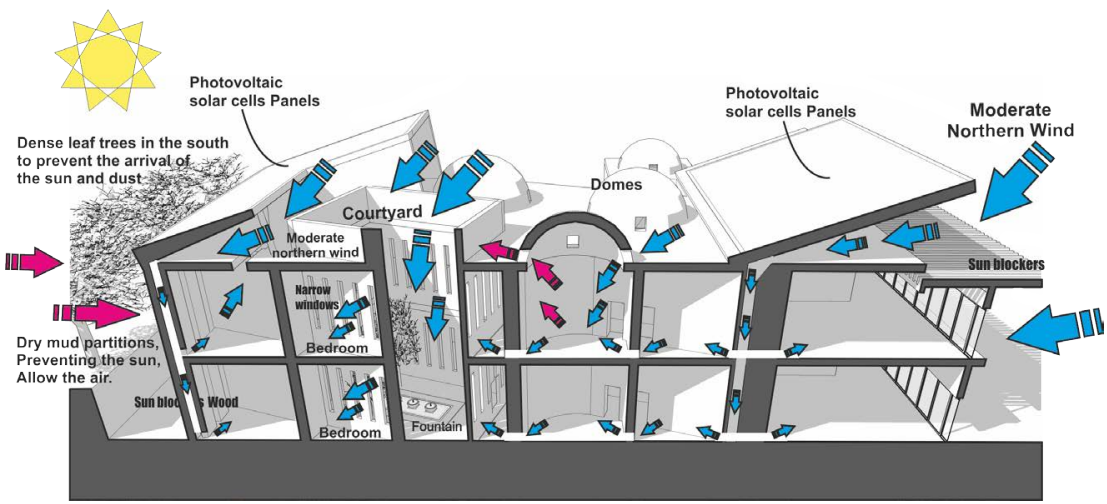

Figure 13. Some methods of applying environmental design, and optimal utilization of natural resources. Also, use wind catchments to be directed to the prevailing wind direction, and Good ventilation seeking to provide thermal comfort inside the building (Author work). 
create a good airflow, and choose natural paints to avoid entering chemicals into buildings and achieving the same result and effectiveness (Figure 13).

7) The use of local eco-friendly materials with positive environmental-supporting effects in terms of their non-impact on global warming, as they are suitable for the environmental conditions of the place, can be recycled and have a positive impact on the public health.

8) Mud is one of the best environmental materials and does not constitute any pollution of the environment during manufacturing, implementation or modification or in the event of demolition and reconstruction of the building or even in the event of abandonment and collapse, it comes from the land and returns to it. Its qualities can be improved by adding some materials, such as plant products, Lime, Fibers, and Bitumen.

9) It is necessary to plant plants beside the southern wall and on the roof of the building to protect the outer surfaces from the sun on summer days, choose deciduous trees at the source of solar radiation, uncover the walls on winter days after the fall of leaves when the sun is needed and surround buildings with groups of evergreen trees.

\section{Recommendations}

1) Recommend generating clean alternative energy from available and nonpolluting sources of the environment, such as the energy generated from the sun and wind.

2) Recommend to energy use efficiency and reduction in wastage in use, benefiting the environment.

3) Reducing the negative impact on the environment in order to preserve natural resources and reduce the negative effects of the hotel industry on the environment while providing a healthy environment for guests.

4) Recommend environmental awareness for all segments of society, and clarify the benefits to people's lives from pre-serving the environment.

5) Reducing water consumption, preserving it, not wasting it, and paying attention to its reuse in other functions.

6) Not to pollute the environment with toxic and harmful wastes and work on recycling and utilizing waste and used materials.

\section{Conflicts of Interest}

The author declares no conflicts of interest regarding the publication of this paper.

\section{References}

[1] Byrne, J.A. (2007) Design (and Ecodesign). In: Encyclopedia of Environment and Society, Sage, Thousand Oaks, CA, 451-453.

https://www.researchgate.net/publication/229090797_EcoDesign

[2] O’Connor, S., Meek, C., Bassok, A. and Kopca, C. (2015) The Value of Green Building LEED Valuation Phase I. MUP-Runstad Center for Real Estate Studies. 
[3] Fowler, K.M. and Rauch, E.M. (2006) Sustainable Building Rating Systems Summary. United States Department of Energy.

[4] Isabelle Flora, F.M., Donatien, N., Tchinda, R. and Hamandjoda, O. (2019) Impact of Sustainable Electricity for Cameroonian Population through Energy Efficiency and Renewable Energies. Journal of Power and Energy Engineering, 7, Article ID: 95094.

[5] Christelle Ketchanji, M.Y., Ndjakomo, E.S. and Moukengue, I.A. (2019) A Simple Predictive Performance Model of Solar Cell under Very Hot and Humide Climate. Journal of Power and Energy Engineering, 7, 26-47.

[6] Sarbu, I. and Sebarchievici, C. (2016) Using Ground-Source Heat Pump Systems for Heating/Cooling of Buildings. https://doi.org/10.5772/61372

[7] Birkhäuser, G.M. (2006) Building with Earth, Design and Technology of a Sustainable Architecture. Architecture, Basel, Berlin, Boston, MA.

[8] International Tourism Partnership (2008) Environmental Management for Hotels, Waste, Waste Management-Objectives. Third Edition 2008.

[9] Banfield, K. and Reardon, C. (2013) yourhome.gov.au. http://www.yourhome.gov.au/housing/noise-control

[10] International Tourism Partnership (2008) Environmental Management for Hotels, WATER. Third Edition 2008.

[11] International Tourism Partnership (2008) Environmental Management for Hotels, Hazardous Materials. Third edition 2008.

[12] Dipasquale, L., Rovero, L. and Fratini, F. (2016) Chemical Additives or Involve Risks to Health. Ancient Stone Masonry Constructions.

[13] Farrant, A. (2017) British Geological Survey, NERC. https://www.bgs.ac.uk/mendips/aggregates/stone_resource/stoneuses.html

[14] Christidis, G.E. (2010) Industrial Clays. https://doi.org/10.1180/EMU-notes.9.9

[15] Oeko-Texcertification, Human Ecology \& Sustainable Textile Production. https://www.centexbel.be/en/certification/oeko-tex-certification

[16] Cuerate: World Class Home Designs. https://www.cuerate.org/3c1V93/j3356G/

[17] Pinterest.com, pin. https://www.pinterest.com/pin/436919601328061434/

[18] Wikipedia.org, Environmental Impact of Paint. https://en.wikipedia.org/wiki/Environmental_impact_of_paint

[19] Cubesmart, Decor-Design, Sustainable Furniture Design-Choosing Eco-Friendly and Green Furniture Options.

https://www.cubesmart.com/blog/inspo/decor-design/sustainable-furniture-designchoosing-eco-friendly-and-green-furniture-options/ 